\title{
Polymorphic Variants of Neurotransmitter Receptor Genes May Affect Sexual Function in Aging Males: Data from the HALS Study
}

\author{
Paweł Jóźków ${ }^{a} \quad$ Małgorzata Słowińska-Lisowska ${ }^{a} \quad$ Łukasz Łaczmańskib $^{b}$ \\ Marek Mędraśa, b \\ ${ }^{a}$ Department of Sports Medicine and Nutrition, University School of Physical Education, and ${ }^{\mathrm{b}}$ Department of \\ Endocrinology, Diabetology and Isotope Treatment, Wrocław Medical University, Wrocław, Poland
}

\section{Key Words}

Dopamine receptor $\cdot$ Melanocortin receptor $\cdot$ Serotonin receptor · Genetics · Genetic polymorphism · Sexual dysfunction · Ageing, males

\begin{abstract}
Background/Aims: Human behavior is influenced by a number of brain neurotransmitters. Central dopamine, serotonin and melanocortin systems have special importance for male sexual function. We searched for associations between male aging symptoms and polymorphic sites of serotonin $\left(5-\mathrm{HTR}_{1 \mathrm{~B}}\right)$, melanocortin (MC4R) and dopamine (DRD2, DRD4) receptors. Methods: In a population-based sample, genotyping of 5-HTR1B (polymorphism: G861C), MC4R (polymorphisms: C-2745T, Val103lle), DRD2 (polymorphism: C313T) and DRD4 (polymorphism: 48-bp VNTR) was performed in 387 healthy men. The Aging Males' Symptoms (AMS) scale was used to evaluate specific ailments of aging men. We analyzed answers to questions from the AMS scale. Five points of the questionnaire addressed sexual symptoms of the aging male: feeling of passing one's peak, decrease in beard growth, decrease in ability/frequency to perform sexually, decrease in the number of morning erections, and decrease in sexual desire/libido (lacking pleasure in sex, lacking desire for sexual intercourse). Relations between reported
\end{abstract}

\section{KARGER}

E-Mail karger@karger.com

www.karger.com/nen symptoms and variants of the polymorphic sites of the studied genes were assessed. Results: After adjusting for confounding factors (education, arterial hypertension, physical activity, weight, waist circumference) an association between the sexual dimension of AMS and genetic variants of 5-HTR1B G861C ( $p=0.04)$ was observed. Conclusions: Variability of neurotransmitter receptor genes may be associated with sexual symptoms of aging in men.

Copyright $\odot 2013$ S. Karger AG, Basel

\section{Introduction}

It is well known that many physiological and psychological conditions in humans are under the control of neuropeptides - serotonin (5-HT), melanocortin (MC) and dopamine (DA). Brain neurotransmitters affect our behavior and ensure intact sexual function [1].

The central dopaminergic system regulates learning, motivation, reward, reinforcing mechanisms/addiction and sexual behavior as well [2]. DA acts through five receptors (DRD1-DRD5), which are present in nearly all areas of the brain. DRD1 and DRD5 activate adenylyl cyclase and increase cyclic adenosine monophosphate (cAMP) production. DRD2, DRD3 and DRD4 exert opposite effects and decrease cAMP production through in- 
hibition of adenylyl cyclase activity [3]. It has been suggested that polymorphisms of the DRD4 gene contribute to sexual desire and arousal [4]. Differences of sexual function were also noted for e.g. variants of DRD4 VNTR polymorphism [5].

5-HT attracts much attention as it mediates emotions and mood. There are at least 14 different 5 -HT receptor subtypes with autoreceptors that regulate 5-HT release and heteroreceptors that are located on dopaminergic, glutamatergic, GABAergic or cholinergic neurons which regulate the release of these neurotransmitters [6]. Depression, suicidal tendencies, impulsive behavior and aggression are associated with disturbed signaling in the brain serotoninergic system. There are several reports on associations between genetic diversity of 5-HT and sexual dysfunction [7-9]. It has been suggested for example that $5-\mathrm{HT}_{1 \mathrm{~B}}$ receptors may be involved in premature ejaculation [10].

MC derives from tissue-specific posttranslational processing of the pre-prohormone proopiomelanocortin. This neurotransmitter exerts its actions through five receptors (MC1R-MC5R). The MC4R subtype affects sexual function and reproduction. MC agonists may influence erectile or other forms of sexual dysfunction [11].

In the framework of the Health of Adults in Lower Silesia (HALS) study, we evaluated the hypothesis that polymorphisms of neurotransmitter receptor genes are associated with a propensity to be active. Such observations have been made for a number of genes and new information is being constantly provided $[12,13]$. Apart from the level of physical activity, recruited subjects were also checked for the presence of aging symptoms. We decided to apply the Aging Males' Symptoms (AMS) scale, which is a standardized psychometric tool, used worldwide, for assessing health-related quality of life in aging men. The scale comprises three dimensions: psychological, somatovegetative and sexual. It assesses symptoms independent of those which are disease-related. Details on the reliability and validity of the scale have been discussed elsewhere $[14,15]$. We wanted to determine whether polymorphisms of the genes encoding receptors for 5-HT, MC and DA are related to aging symptoms in healthy men.

\section{Materials and Methods}

Our investigation was carried out within a broader project named the HALS study. The project of the study was approved by the Bioethics Committee at the University School of Physical Education, Wrocław.
We sent invitations to 900 adult men living in Lower Silesia. The region of Lower Silesia lies in southern Poland, covers an area of $19,947 \mathrm{~km}^{2}$, and has a population of 2,880,000 (100\% Caucasian). Men were chosen at random from the local data bank (regional statistical office). Personal identification number was used as an identifier. From the target group, 387 subjects (43\%) provided written consent and were enrolled in the study. We did not encounter any subjects of origin other than European. The homogeneous origin of the investigated men allowed us to compare polymorphisms of the studied genes. We did not study the nonresponding group.

Recruited subjects underwent a standard medical interview and physical examination with anthropological measurements (table 1).

Each man completed the AMS scale under supervision of the researchers. A detailed description of the AMS scale application can be found on a website (http://www.aging-males-symptomsscale.info/). We were particularly interested in the AMS sexual subscale in which $\leq 5,6-7,8-10$ and $\geq 10$ points indicate presence of respectively no (or slight), mild, moderate and severe disturbances. For the purpose of the present investigation, only subjects aged $\geq 40$ were included $(n=240)$.

We evaluated polymorphic regions of genes encoding receptors for: 5-HT - 5-HTR1B (G861C); MC - MC4R (C-2745T, Val103Ile), and DA - DRD2 and DRD4 (C313T, 48-bp VNTR). The details of the genotyping of 5-HT, MC and DA receptors have been described in our previous reports [16-18].

\section{Statistical Analysis}

The analysis of variance (to test the hypothesis of a difference of means) and Kruskal-Wallis test (to test the hypothesis of a difference of distributions) were employed to investigate the associations between the studied genotypes and the symptoms of aging.

Relations between the symptoms of aging and the number of repeats in the polymorphic sites were assessed using the t test (to test the hypothesis of a difference of means) and the Mann-Whitney $\mathrm{U}$ test (to test the hypothesis of a difference of distributions). The analysis of associations between anthropological parameters and the results of the AMS scale was performed using Pearson's coefficient of correlation.

One-dimensional analysis of variance and logistic regression were used to assess educational status, anthropological parameters and chronic conditions that could have an impact on sexual symptoms in aging males. A $\mathrm{p}$ value $<0.05$ was considered significant. All calculations were done with StatSoft, Inc., Statistica for Windows, version 9.0 (data analysis software system; www.statsoft. com).

\section{Results}

The relationships between the AMS scale as a whole and the investigated polymorphisms of genes encoding receptors for 5-HT, MC and DA appeared to be statistically significant (one-dimensional ANOVA) for 5-HTR $1 B$ G861C ( $\mathrm{p}=0.02)$ and $M C 4 R C-2745 T(\mathrm{p}=0.01)$ and insignificant for MC4R Val103Ile ( $\mathrm{p}=0.46), D R D 2$ C313T $(\mathrm{p}=0.84)$ and DRD4 48-bp VNTR $(\mathrm{p}=0.13)$. 
Table 1. Characteristics of the study group

\begin{tabular}{|c|c|c|c|c|c|c|c|}
\hline Age, years & 54.5 & 54.0 & 40.0 & 72.0 & 49.0 & 62.0 & 7.9 \\
\hline Weight, kg & 85.4 & 85.0 & 54.0 & 132.0 & 76.0 & 94.5 & 13.7 \\
\hline Height, cm & 174.1 & 174.0 & 159.0 & 196.0 & 170.0 & 179.0 & 6.6 \\
\hline Body mass index & 28.1 & 27.5 & 19.5 & 42.9 & 25.1 & 30.7 & 4.1 \\
\hline Systolic blood pressure, $\mathrm{mm} \mathrm{Hg}$ & 133.7 & 130.0 & 90.0 & 200.0 & 120.0 & 145.0 & 17.1 \\
\hline Diastolic blood pressure, $\mathrm{mm} \mathrm{Hg}$ & 85.8 & 85.0 & 60.0 & 120.0 & 80.0 & 90.0 & 10.4 \\
\hline Education $>12$ years, $\%$ & 43 & & & & & & \\
\hline Cigarette smoking, $\%$ & 25 & & & & & & \\
\hline Arterial hypertension, \% & 21 & & & & & & \\
\hline
\end{tabular}

The sexual dimension of the AMS scale was associated (one-dimensional ANOVA including five polymorphic sites) with genetic variants of 5-HTR1B G861C $(\mathrm{p}=0.01)$ and MC4R C-2745T ( $\mathrm{p}=0.02)$ and was on the verge of statistical significance in the case of DRD4 48-bp VNTR $(\mathrm{p}=0.05)$.

The relationship between the AMS sexual subscale and the polymorphic site of the $5-\mathrm{HT}$ receptor $5-H T R 1 B$ G861C is presented in figure $1 . \mathrm{G} / \mathrm{G}$ homozygotes had more symptoms than $\mathrm{C} / \mathrm{C}$ homozygotes and the lowest number of sexual problems was reported by heterozygotes $(\mathrm{C} / \mathrm{G})$.

A similar situation was observed for different types of the MC4R C-2745T gene (fig. 2). Sexual disturbances were found more often in $\mathrm{T} / \mathrm{T}$ homozygotes than in $\mathrm{C} / \mathrm{T}$ or $\mathrm{C} / \mathrm{C}$ variants.

We noted that the age-related sexual dysfunction reveals an association with the DRD4 48-bp VNTR polymorphism as well (fig. 3). Men with seven or more repetitions in the variable region had considerably more sexual symptoms than men who had fewer repetitions in this specific site.

A set of analyses was performed to search for factors that could interfere with these results. It showed that a lower number of sexual symptoms is associated with higher education (fig. 4).

Among chronic conditions reported by our study subjects, only presence of arterial hypertension (but not sys- tolic or diastolic blood pressure itself) was associated with the degree of sexual dysfunction (table 2).

We found a low but statistically significant correlation between the AMS sexual subscale and body weight and waist circumference (table 3 ).

Higher body mass and bigger waist circumference imply more sexual symptoms. This is in concordance with the observation that men who are sedentary report more disturbances in this regard (fig. 5).

Finally, a logistic regression model comprising three of the studied polymorphisms (5-HTR1B G861C, MC4R $C-2745 T$ and DRD4 48-bp VNTR) and the confounding factors: education, arterial hypertension, physical activity level, body mass and waist circumference showed that a lower number of sexual symptoms $(\leq 7)$ can be expected in 5-HTR1B G861C G/C heterozygotes ( $\mathrm{p}=0.04$ ) (table 4).

\section{Discussion}

Information on associations between genetic polymorphisms and sexual function of males (in particular older males) is scarce. One of the first attempts to investigate this problem was a study on genetically determined CAG polymorphism of the androgen receptor gene and AMS. The authors of the report found certain correlations between CAG number and the AMS global score, 
Fig. 1. Associations between the number of sexual symptoms (AMS scale) and variants of 5-HTR1B G861C.

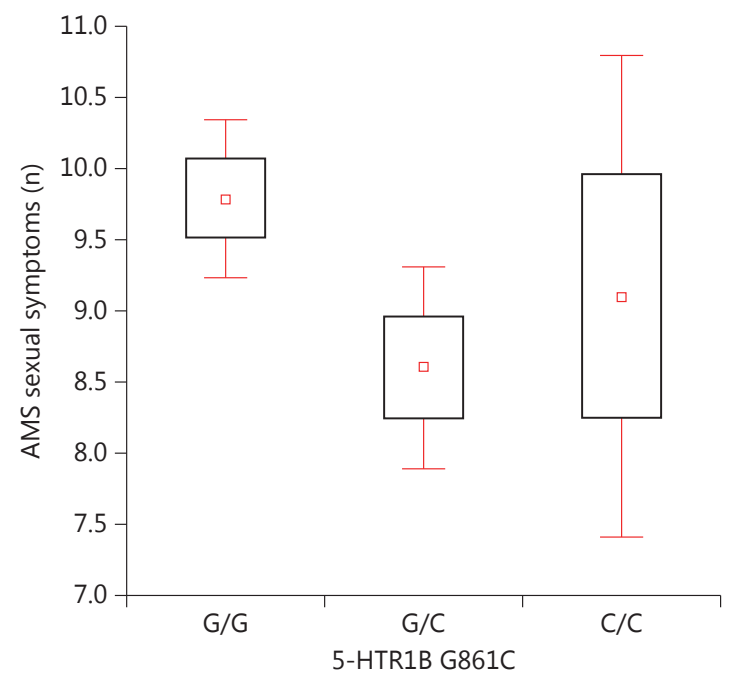

- Mean

$\square$ Mean \pm SD

$\mp$ Mean $\pm 1.96 \mathrm{SE}$

\begin{tabular}{|l|r|r|r|r|r|}
\hline & \multicolumn{4}{|c|}{ One-dimensional significance test for AMS sexual symptoms } \\
\hline Effect & \multicolumn{1}{|c|}{ SS } & degrees of freedom & MS & F & \multicolumn{1}{c|}{$p$} \\
\hline Free word & $10,473.60$ & 1 & $10,473.60$ & 918.9226 & 0.000000 \\
\hline 5-HTR1B G861C & 73.45 & 2 & 36.72 & 3.2221 & 0.041618 \\
\hline Error & $2,712.65$ & 238 & 11.40 & & \\
\hline
\end{tabular}

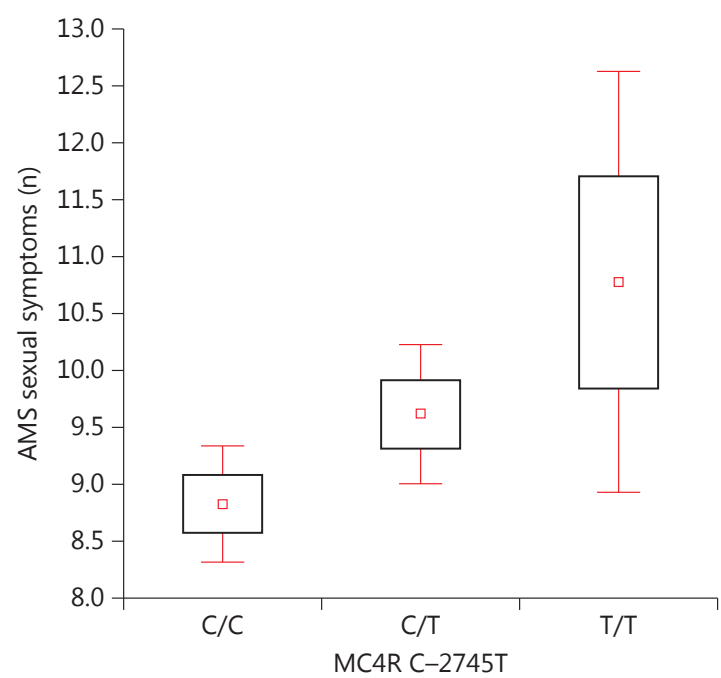

- Mean

$\square$ Mean \pm SD

\pm Mean $\pm 1.96 \mathrm{SE}$

MC4R C-2745T

\begin{tabular}{|l|r|r|r|r|r|}
\hline & \multicolumn{4}{|c|}{ One-dimensional significance test for AMS sexual symptoms } \\
\hline Effect & \multicolumn{1}{|c|}{ SS } & degrees of freedom & MS & F & \multicolumn{1}{c|}{$p$} \\
\hline Free word & $14,487.95$ & 1 & $14,487.95$ & $1,301.871$ & 0.000000 \\
\hline MC4R C-2745T & 94.76 & 2 & 47.38 & 4.257 & 0.015077 \\
\hline Error & $3,149.38$ & 283 & 11.13 & & \\
\hline
\end{tabular}

Fig. 2. Associations between the number of sexual symptoms (AMS scale) and variants of MC4R C-2745T. 
Fig. 3. Associations between the number of sexual symptoms (AMS scale) and variants of DRD4 48-bp VNTR.

Fig. 4. Mean number of sexual symptoms in relation to years of education ( $>12$ years of education translate into fewer symptoms).

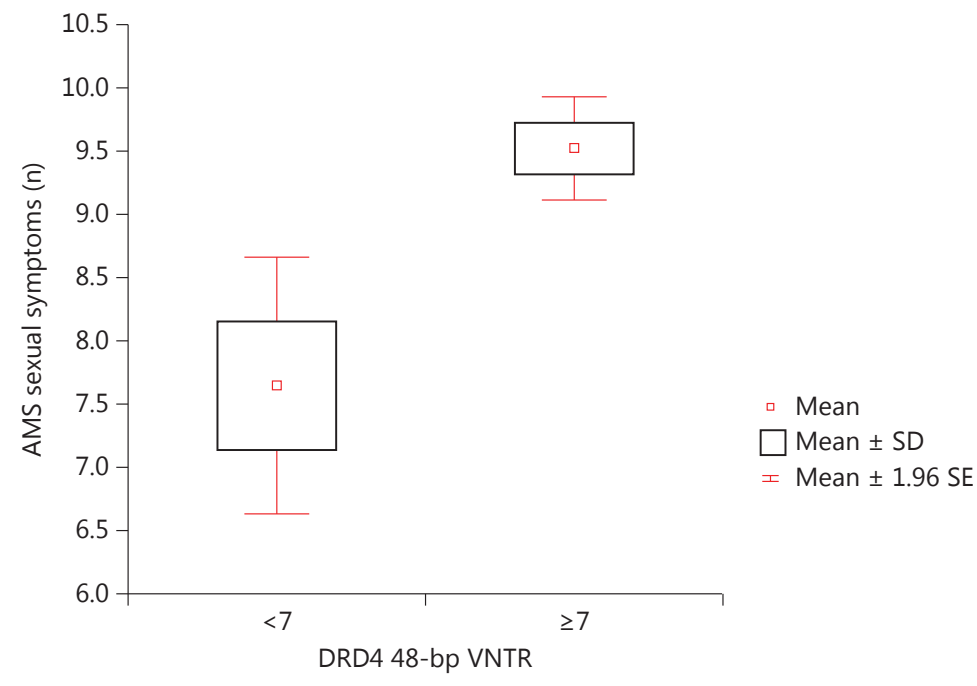

\begin{tabular}{|l|r|r|r|r|c|}
\hline & \multicolumn{5}{|c|}{ One-dimensional significance test for AMS sexual symptoms } \\
\hline Effect & \multicolumn{1}{|c|}{ SS } & degrees of freedom & \multicolumn{1}{c|}{ MS } & \multicolumn{1}{c|}{ F } & \multicolumn{1}{c|}{$p$} \\
\hline Free word & $7,441.911$ & 1 & $7,441.911$ & 667.7569 & 0.000000 \\
\hline DRD4 48-bp VNTR & 88.633 & 1 & 88.633 & 7.9530 & 0.005137 \\
\hline Error & $3,187.367$ & 286 & 11.145 & & \\
\hline
\end{tabular}

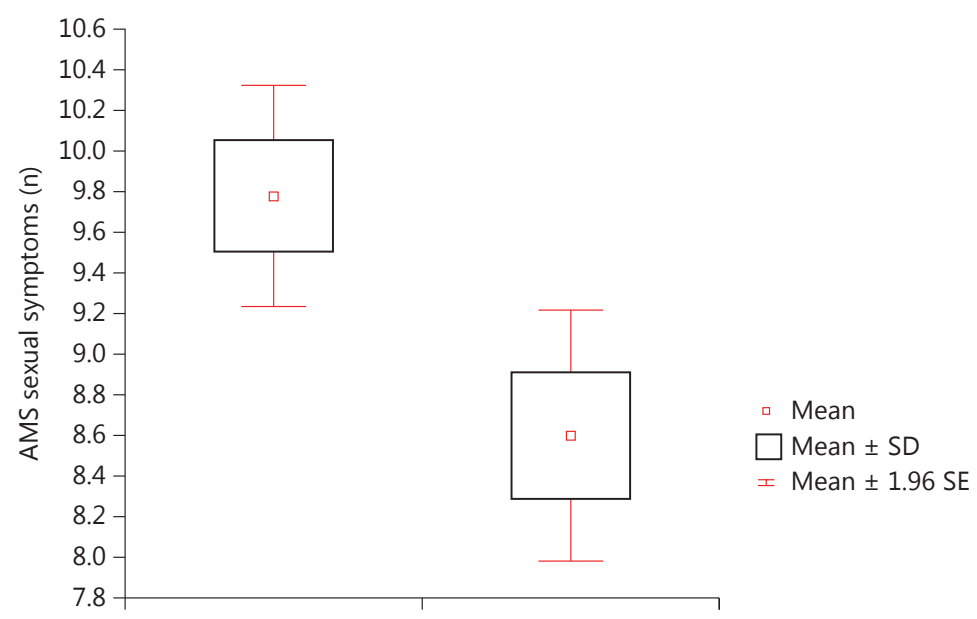

Education

\begin{tabular}{|l|r|r|r|r|c|}
\hline & \multicolumn{5}{|c|}{ One-dimensional significance test for AMS sexual symptoms } \\
\hline Effect & \multicolumn{1}{|c|}{ SS } & degrees of freedom & \multicolumn{1}{c|}{ MS } & \multicolumn{1}{c|}{ F } & \multicolumn{1}{c|}{$\mathrm{p}$} \\
\hline Free word & $21,363.26$ & 1 & $21,363.26$ & $1,861.694$ & 0.000000 \\
\hline Education & 88.03 & 1 & 88.03 & 7.672 & 0.006010 \\
\hline Error & $3,006.50$ & 262 & 11.48 & & \\
\hline
\end{tabular}


Fig. 5. Associations between the number of sexual symptoms (AMS scale) and the level of physical activity.

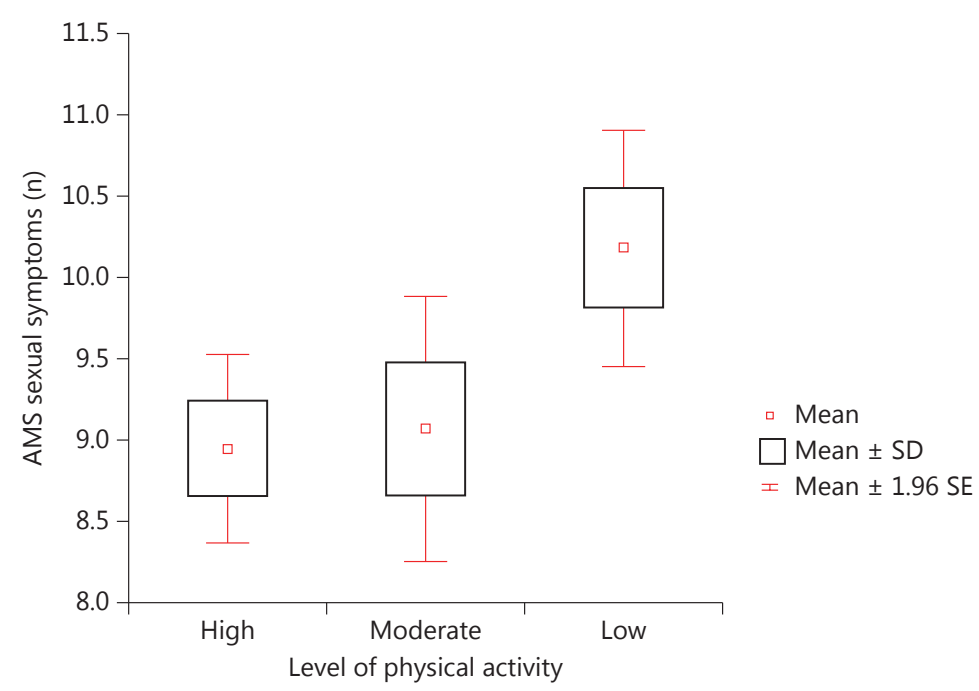

\begin{tabular}{|l|r|r|r|r|c|}
\hline & \multicolumn{5}{|c|}{ One-dimensional significance test for AMS sexual symptoms } \\
\hline Effect & \multicolumn{1}{|c|}{ SS } & degrees of freedom & MS & \multicolumn{1}{c|}{ F } & \multicolumn{1}{c|}{$p$} \\
\hline Free word & $21,860.50$ & 1 & $21,860.50$ & $2,007.086$ & 0.000000 \\
\hline Level & 73.40 & 2 & 36.70 & 3.369 & 0.035928 \\
\hline Error & $2,820.94$ & 259 & 10.89 & & \\
\hline
\end{tabular}

the psychological and somatic subscale, but not the sexual subscale [19]. We assessed male aging symptoms in the context of genetic variants of receptors for three neuropeptides - DA, 5-HT and MC.

It is well known that nuances of neurotransmission interfere with the sexual function of males [20]. DA effects on sexual behavior can probably be explained by the influence on motor functions and general arousal. Preoptic and paraventricular nucleus release of DA may have some relationship with mechanisms of ejaculation or with the neuroendocrine consequences of sexual activity, or they may be related to other autonomic processes associated with copulation [21]. It was proven that aging is associated with a decrease of DA receptors in striatal and extrastriatal regions of the brain [22]. A considerable, agerelated decline is also observed in the serotoninergic system, independently of the disease [23].

After noting that a DRD4 agonist induces penile erection in rats, it was found that variants of the DRD4 gene may be related to phenotypes of human sexual behavior. In a study performed in 148 nonclinical university students, the single most common DRD4 5-locus haplotype was associated with desire, function and arousal scores
[4]. It has also been hypothesized that sexual dysfunction in men receiving selective 5 -HT reuptake inhibitors may be dependent on the variability of the $D R D 2$ gene [7]. Furthermore, Chinese authors reported that sexual dysfunction is found more often in patients with schizophrenia who have a higher frequency of the Ins allele of the DRD2-141C Ins/Del polymorphism [24]. In our investigation there was no association between the DRD2 C313T polymorphism and the sexual scale of AMS. Nevertheless, we found that the association between this aspect of aging and the DRD4 48-bp VNTR polymorphism in exon III of chromosome 11 is close to statistical significance. This variable region of the DA D4 receptor gene usually contains 2-11 tandem repeats. If the number of alleles is $\geq 7$, the binding affinity and receptor density in the corticomesolimbic regions are lower. A higher number of repeats are associated with novelty seeking and a number of conditions such as attention deficit hyperactivity disorder, alcoholism, financial risk-taking, disinhibition and impulsivity [5]. In a young population a relation between $\mathrm{DRD} 4$ genotype and the number of previous sexual partners was found [25]. In a recent study, young individuals genotyped as $\geq 7$ were more likely to engage in promiscu- 
Table 2. Relationships between the number of sexual symptoms (AMS scale) and chronic diseases

\begin{tabular}{|c|c|c|c|c|c|c|c|c|c|c|}
\hline & Presence & Mean & SD & Min. & $\begin{array}{l}\text { Lower } \\
\text { quartile }\end{array}$ & Median & $\begin{array}{l}\text { Upper } \\
\text { quartile }\end{array}$ & Max. & & $\begin{array}{l}\text { at's t test/ } \\
\text {-Whitney U test }\end{array}$ \\
\hline Arterial hypertension & no & 9.00 & 3.24 & 5.0 & 6.0 & 9.0 & 11.0 & 20.0 & a & $0.0141 / 0.0193$ \\
\hline \multirow[t]{2}{*}{ Atherosclerosis } & no & 9.33 & 3.38 & 5.0 & 6.0 & 9.0 & 12.0 & 21.0 & a & $0.7835 / 0.9147$ \\
\hline & yes & 9.00 & 2.72 & 5.0 & 6.5 & 9.5 & 11.5 & 12.0 & a & \\
\hline Diabetes mellitus & yes & 10.42 & 4.10 & 5.0 & 7.0 & 10.0 & 12.0 & 21.0 & a & \\
\hline \multirow[t]{2}{*}{ Low back pain } & no & 9.17 & 3.35 & 5.0 & 6.0 & 9.0 & 12.0 & 21.0 & a & $0.1796 / 0.1953$ \\
\hline & yes & 9.78 & 3.38 & 5.0 & 7.0 & 10.0 & 12.0 & 20.0 & a & \\
\hline \multirow[t]{2}{*}{ Benign prostate hyperplasia } & no & 9.22 & 3.32 & 5.0 & 6.0 & 9.0 & 12.0 & 21.0 & $\mathrm{a}$ & $0.0964 / 0.1075$ \\
\hline & yes & 10.42 & 3.71 & 5.0 & 7.0 & 10.0 & 13.0 & 20.0 & $\mathrm{a}$ & \\
\hline
\end{tabular}

Table 3. Correlations between the AMS sexual subscale and anthropological parameters

\begin{tabular}{llc}
\hline & Correlation & AMS sexual subscale \\
\hline Weight & Pearson's & $0.12^{*}$ \\
Height & Pearson's & -0.05 \\
Waist circumference & Pearson's & $0.14^{*}$ \\
Hip circumference & Pearson's & 0.08 \\
Systolic blood pressure & Pearson's & 0.08 \\
Diastolic blood pressure & Pearson's & -0.012 \\
\hline
\end{tabular}

* Statistically significant.

Table 4. Model of logistic regression for the studied parameters (pseudo- $R^{2}-0.0391 ; R^{2}$ Nagelkerke $-0.0687 ; R^{2}$ Cox-Snell - 0.0504)

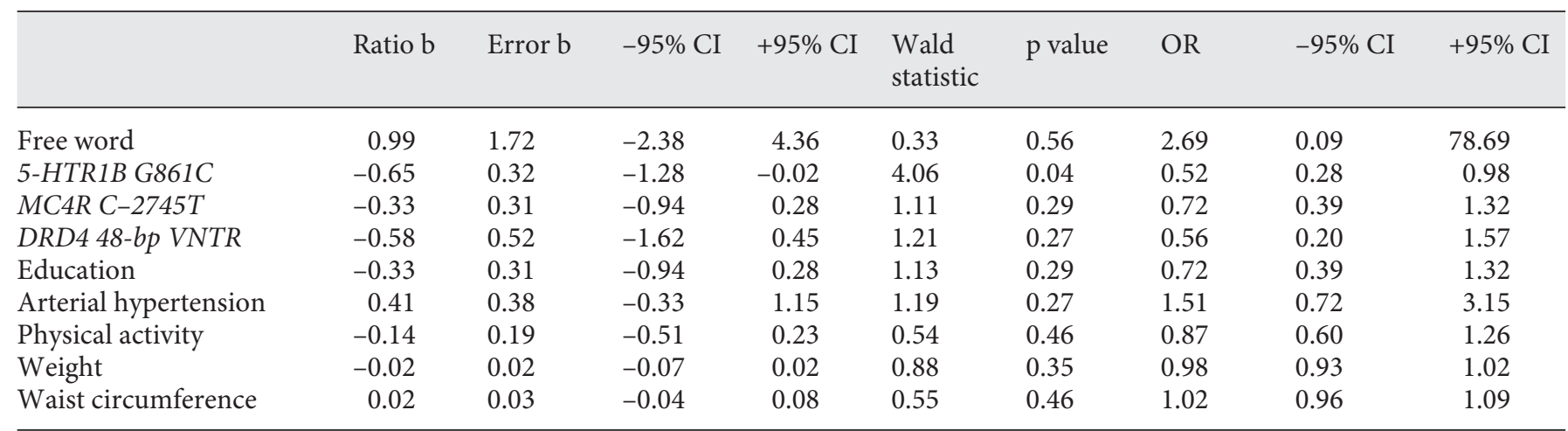

ous sex, which - under certain conditions - could lead to greater offspring diversity and increased fecundity. The authors of the study implied that in environments where monogamy and fidelity are disadvantageous, the DRD4 48 - $b p$ VNTR variant with $\geq 7$ repeats would be positively selected [5]. Our study subjects with $\geq 7$ repeats tended to have more sexual symptoms than ones with $<7$ repeats (ns). Whether it could support earlier observations on the influence of the dopaminergic reward pathway on the sexual function in these subjects is an open question. 
There is no doubt that 5-HT - together with DA - affects our emotions and mood. There are extensive data on associations between brain 5-HT and sexual function [26]. Generally, reduction of 5-HT function facilitates and enhancement inhibits sexual behavior in rodents [27]. Some observations suggest that both $5-\mathrm{HT}_{1 \mathrm{~B}}$ and $5-\mathrm{HT}_{1 \mathrm{~A}}$ receptors participate in inhibitory effects of the neurotransmitter on sexual behavior of mice [28]. More recent research indicates that certain pools of $5-\mathrm{HT}_{1 \mathrm{~A}}$ receptors are crucial for activating sexual behavior. The role of $5-\mathrm{HT}_{1 \mathrm{~B}}$ receptors is less well defined, although they are also involved in these mechanisms (together with 5- $\mathrm{HT}_{2 \mathrm{~A} / \mathrm{B}}$ and $5-\mathrm{HT}_{7}$ receptors) [27]. In human studies it has been confirmed that sexual side effects of antidepressants are mediated by 5-HT receptors. For example, men with a GG genotype of the $5-\mathrm{HT}_{2 \mathrm{~A}}$ receptor gene are more likely to have sexual dysfunction than AA homozygotes or GA heterozygotes $(\mathrm{OR}=3.6 ; 95 \%$ CI 1.03, 12.6; $\mathrm{p}=$ 0.046 ) [9]. We found a clear association between $5-\mathrm{HT}_{1 \mathrm{~B}}$ receptor G861C polymorphism and sexual function of men $>40$. G/C heterozygotes had statistically fewer sexual symptoms than homozygotes. The role of this polymorphism was further confirmed in a logistic regression model. At this point we are unable to translate these slight differences into clinical significance.

The central MC system is of special interest as a possible target for pharmacological interventions in sexual dysfunction in both men and women. Huge expectations are placed on agents modifying MC pathways (and MC receptors) in men with erectile dysfunction. In animals, it was noted that intracerebroventricular administration of $\alpha$-melanocyte-stimulating hormone ( $\alpha-\mathrm{MSH})$ increases sexual motivation and stimulates sexual behaviors while application of an MC4 antagonist delays the onset of male sexual behavior [29]. More recently it was found that antagonists of MC4R (melanotan II, PT-141) induced transient erections in men with erectile dysfunction. Improvements in this aspect were also seen when an agonist of MC4R was used (LY2112688) [30]. We have not encountered any information on associations between $M C 4 R$ polymorphism and sexual symptoms in aging men in the literature. However, analysis of our data revealed a considerably higher score of sexual ailments in the T/T homozygotes as compared with the other variants of the $M C 4 R C-2745 T$ polymorphism (not confirmed in a logistic regression model). A more prevalent sedentary lifestyle and lower level of physical activity of the T/T homozygotes [31] could explain (at least potentially) their worse health status.
It is necessary to mention several limitations of the present study. We happened to make our observations while searching for associations between neurotransmitter receptor polymorphisms and the level of physical activity. The genetic sites for the study were chosen because of their involvement in the locomotor activity of humans [32]. We keep in mind that our results could be affected by factors that were not covered by the survey (e.g. marital status or sexual orientation). Although we aimed to gather a representative, population-based sample of men, we received only a modest response from the invited subjects. More than $40 \%$ of the volunteers held a university degree and we found that longer education was associated with fewer symptoms. We underlined a higher than average level of physical activity of the enrolled men in our previous publication [18]. The major strength of this study is that the investigated men derived from a genetically homogeneous region, they were generally healthy and did not receive drugs that could interfere with the measurements. The scale to evaluate aging symptoms has often been used in our setting $[33,34]$. We understand that our observations have to be confirmed in other populations with precisely defined and controlled parameters of the sexual function phenotype. At the same time there is a need for exploring mechanisms by which these specific genetic variants could result in observed phenotypes.

We conclude that sexual symptoms seem to be associated with polymorphic variants of the 5-HT receptor gene in aging men. Some indices suggest possible relations with $\mathrm{MC}$ and DA receptor genes as well. Further research is needed to confirm our preliminary findings.

\section{Acknowledgement}

This work was supported by the Ministry of Science and Higher Education of Poland (grant code 2PO5D 0730).

References

Jóźków/Słowińska-Lisowska/Łaczmański/ Mędraś
1 Moll JL, Brown CS: The use of monoamine pharmacological agents in the treatment of sexual dysfunction: evidence in the literature. J Sex Med 2011;8:956-970.

2 Dominguez JM, Hull EM: Dopamine, the medial preoptic area, and male sexual behavior. Physiol Behav 2005;86:356-368.

- 3 Knab AM, Lightfoot JT: Does the difference between physically active and couch potato lie in the dopamine system? Int J Biol Sci 2010;6: $133-150$. 
-4 Ben Zion IZ, Tessler R, Cohen L, Lerer E, Raz Y, Bachner-Melman R, Gritsenko I, Nemanov L, Zohar AH, Belmaker RH, Benjamin J, Ebstein RP: Polymorphisms in the dopamine D4 receptor gene (DRD4) contribute to individual differences in human sexual behavior: desire, arousal and sexual function. Mol Psychiatry 2006;11:782-786.

5 Garcia JR, MacKillop J, Aller EL, Merriwether AM, Wilson DS, Lum JK: Associations between dopamine D4 receptor gene variation with both infidelity and sexual promiscuity. PLoS One 2010;5:e14162.

-6 Miszkiel J, Filip M, Przegalinski E: Role of serotonin $\left(5-\mathrm{HT}_{1 \mathrm{~B}}\right)$ receptors in psychostimulant addiction. Pharmacol Rep 2011;63:1310 1315.

-7 Strohmaier J, Wust S, Uher R, Henigsberg N, Mors O, Hauser J, Souery D, Zobel A, Dernovsek MZ, Streit F, Schmal C, Kozel D, Placentino A, Farmer A, McGuffin P, Aitchison KJ, Rietschel M: Sexual dysfunction during treatment with serotonergic and noradrenergic antidepressants: clinical description and the role of the 5-HTTLPR. World J Biol Psychiatry $2011 ; 12: 528-538$.

-8 Blom RM, Samuels JF, Riddle MA, Joseph Bienvenu O, Grados MA, Reti IM, Eaton WW, Liang KY, Nestadt G: Association between a serotonin transporter promoter polymorphism (5HTTLPR) and personality disorder traits in a community sample. J Psychiatr Res 2011;45:1153-1159.

-9 Bishop JR, Moline J, Ellingrod VL, Schultz SK, Clayton AH: Serotonin 2A -1438 G/A and Gprotein $\beta 3$ subunit $\mathrm{C} 825 \mathrm{~T}$ polymorphisms in patients with depression and SSRI-associated sexual side effects. Neuropsychopharmacology 2006;31:2281-2288.

10 Andersson KE, Abdel-Hamid IA: Therapeutic targets for premature ejaculation. Maturitas 2011;70:26-33.

11 Hellstrom WJ: Clinical applications of centrally acting agents in male sexual dysfunction. Int J Impot Res 2008;20(suppl 1):S17S23.

12 Roth SM, Rankinen T, Hagberg JM, Loos RJ, Pérusse L, Sarzynski MA, Wolfarth B, Bouchard C: Advances in exercise, fitness, and performance genomics in 2011. Med Sci Sports Exerc 2012;44:809-817.
13 Kalupahana NS, Moustaid-Moussa N, Kim JH, Voy BH, Bassett D, Bray MS, Lightfoot JT: The regulation of physical activity by genetic mechanisms: is there a drive to be active? In Bouchard C, Hoffman EP (eds): Genetic and Molecular Aspects of Sport Performance. Chichester, Blackwell, 2011, pp 283-293.

14 Heinemann LA, Saad F, Zimmermann T, Novak A, Myon E, Badia X, Potthoff P, T'Sjoen G, Pollanen P, Goncharow NP, Kim S, Giroudet C: The Aging Males' Symptoms (AMS) scale: update and compilation of international versions. Health Qual Life Outcomes 2003; $1: 15$.

15 Heinemann LA: Aging Males' Symptoms scale: a standardized instrument for the practice. J Endocrinol Invest 2005;28:34-38.

16 Jozkow P, Slowinska-Lisowska M, Laczmanski L, Medras M: DRD2 C313T and DRD4 48bp VNTR polymorphisms and physical activity of healthy men in Lower Silesia, Poland (HALS study). Ann Hum Biol 2012.

17 Haber E, Słowińska-Lisowska M, Jóźków P, Łaczmański Ł, Mędraś M: Relationships between the G861C polymorphism of the $5-\mathrm{HT}_{1 \mathrm{~B}}$ serotonin receptor gene and the physical activity in men. Adv Clin Exp Med 2010; 19:455-459.

18 Jozkow P, Slowinska-Lisowska M, Laczmanski L, Jakubiec D, Medras M: Melanocortin-4 receptor gene polymorphism and the level of physical activity in men (HALS study). Endocrine 2011;39:62-68.

19 Schneider G, Nienhaus K, Gromoll J, Heuft G, Nieschlag E, Zitzmann M: Aging males' symptoms in relation to the genetically determined androgen receptor CAG polymorphism, sex hormone levels and sample membership. Psychoneuroendocrinology 2010;35: 578-587.

20 Hull EM, Lorrain DS, Du J, Matuszewich L, Lumley LA, Putnam SK, Moses J: Hormoneneurotransmitter interactions in the control of sexual behavior. Behav Brain Res 1999;105: 105-116.

21 Paredes RG, Agmo A: Has dopamine a physiological role in the control of sexual behavior? A critical review of the evidence. Prog Neurobiol 2004;73:179-226.

22 Kaasinen V, Vilkman H, Hietala J, Nagren K, Helenius H, Olsson H, Farde L, Rinne J: Agerelated dopamine $\mathrm{D} 2 / \mathrm{D} 3$ receptor loss in extrastriatal regions of the human brain. Neurobiol Aging 2000;21:683-688.
23 Barnes NM, Sharp T: A review of central 5 -HT receptors and their function. Neuropharmacology 1999;38:1083-1152.

-24 Zhang XR, Zhang ZJ, Zhu RX, Yuan YG, Jenkins TA, Reynolds GP: Sexual dysfunction in male schizophrenia: Influence of antipsychotic drugs, prolactin and polymorphisms of the dopamine D2 receptor genes. Pharmacogenomics 2011;12:1127-1136.

25 Halpern CT, Kaestle CE, Guo G, Hallfors DD: Gene-environment contributions to young adult sexual partnering. Arch Sex Behav 2007; 36:543-554.

26 Giuliano F: Neurophysiology of erection and ejaculation. J Sex Med 2011;8(suppl 4):310315.

27 Olivier B, Chan JS, Snoeren EM, Olivier JD, Veening JG, Vinkers $\mathrm{CH}$, Waldinger $\mathrm{MD}$, Oosting RS: Differences in sexual behaviour in male and female rodents: role of serotonin. Curr Top Behav Neurosci 2011;8:15-36.

28 Rodriguez-Manzo G, Lopez-Rubalcava C, Hen R, Fernandez-Guasti A: Participation of $5-\mathrm{HT}_{1 \mathrm{~B}}$ receptors in the inhibitory actions of serotonin on masculine sexual behaviour of mice: pharmacological analysis in $5-\mathrm{HT}_{1 \mathrm{~B}}$ receptor knockout mice. Br J Pharmacol 2002. 136:1127-1134.

29 Wikberg JE, Mutulis F: Targeting melanocortin receptors: an approach to treat weight disorders and sexual dysfunction. Nat Rev Drug Discov 2008;7:307-323.

30 Tao YX: The melanocortin-4 receptor: physiology, pharmacology, and pathophysiology. Endocr Rev 2010;31:506-543.

- 31 Loos RJ, Rankinen T, Tremblay A, Pérusse L, Chagnon Y, Bouchard C: Melanocortin-4 receptor gene and physical activity in the Québec Family Study. Int J Obes (Lond) 2005;29: 420-428.

32 Jozkow P, Slowinska-Lisowska M, Laczmanski L, Medras M: Associations between melanocortin, dopamine and serotonin neurotransmission and physical activity. Med Sport 2012;16:40-45.

-33 Jankowska EA, Szklarska A, Lopuszanska M, Medras M: Age and social gradients in the intensity of aging males' symptoms in Poland. Aging Male 2008;11:83-88.

- 34 Trzmiel-Bira A, Filus A, Kuliczkowska-Plaksej J, Laczmanski L, Medras M: The androgen receptor gene polymorphism and clinical picture of androgen deficiency syndrome during aging male of men's population in Wrockaw (in Polish). Endokrynol Pol 2009;60:370-378. 